\title{
COVID-19 Cases among veterinary practitioners: role played by canine patients in Lagos State
}

\author{
Folajimi 0. Shorunke ( $\nabla$ shorunkef@live.com ) \\ Nigerian Field Epidemiology and Laboratory Training Program, Abuja, Nigeria.

\section{Emmanuel Okolocha} \\ Department of Veterinary Public Health, Faculty of Veterinary Medicine, Ahmadu Bello University, Zaria, Nigeria.

\section{S. N. Grace} \\ Department of Veterinary Public Health, Faculty of Veterinary Medicine, Ahmadu Bello University, Zaria, Nigeria.

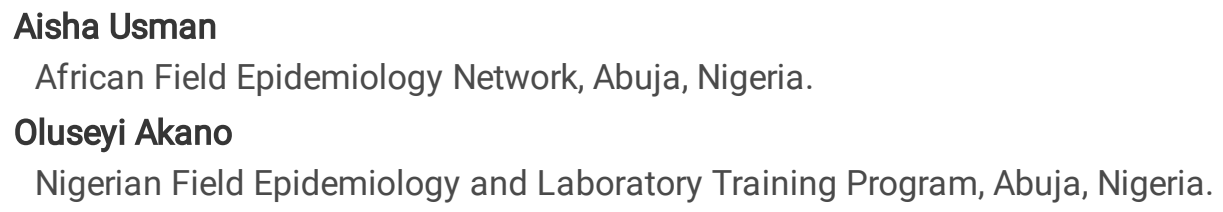

\section{Research Article}

Keywords: Veterinary Practitioners, Canine, COVID-19, Lagos

Posted Date: August 13th, 2021

DOI: https://doi.org/10.21203/rs.3.rs-668868/v1

License: (c) (i) This work is licensed under a Creative Commons Attribution 4.0 International License. Read Full License 


\section{Abstract}

Background COVID-19 was first reported in Nigeria on Feb 27, 2020, as at 9th May 2021 there were 165,382 confirmed cases with 2,065 deaths CFR $1.3 \%$, Lagos accounted for $35 \%$ of the cases and $21 \%$ of deaths nationwide. Veterinarians play an important role in public health, attending to animal patients and owners, with risk of contracting the virus. We provided epidemiological information on covid-19 among veterinary practitioners and canine contacts in Lagos, during the lockdown and analyzed possible associations.

Methods Study carried out in Lagos State, multistage sampling technique used. 5 public and 4 private veterinary facility selected randomly, Clinic registers reviewed and canine blood sample collected for COVID-19 IgG/lgM antibody test. Questionnaires administered to veterinary practitioners in selected facilities, and encouraged to take COVID-19 test. We conducted descriptive statistics using charts, tables and maps, bivariate analysis done, all significant associations at this level was subjected to multivariate analysis.

Result Of the 154 canine and 112 veterinary practitioners sampled, $2 \%$ of canine and $25.9 \%$ of veterinary practitioners returned positive COVID-19 results. Associations were found between returning positive COVID-19 result and residing in Ikeja (OR $=4.12$; $\mathrm{Cl} 1.52-11.2, \mathrm{P} 0.004)$ urban settlement $(\mathrm{OR}=5.72 ; \mathrm{Cl} 1.60-20.44, \mathrm{P} 0.003)$ being a veterinary doctor $(\mathrm{OR}=3.64 ; \mathrm{Cl} 1.40-9.46, \mathrm{P}$ $0.009)$ having tertiary education $(\mathrm{OR}=3.74 ; \mathrm{Cl} 1.04-13.49 \mathrm{P} 0.05)$. Being married was protective $(\mathrm{OR}=0.38 ; \mathrm{Cl} 0.16-0.93, \mathrm{P}$ $0.04)$. Only residing in Ikeja was significant at multivariate level.

Conclusion In conclusion, 3 canine positive COVID-19 cases where recorded in Ikeja and Ikorodu LGAs, veterinary practitioners had COVID-19 prevalence of 25.9\%, associated with residing in Ikeja, urban settlement, being single, being a veterinary doctor, and having tertiary education. No significant relationship found between covid-19 positive veterinary practitioners and canine contacts. We recommended the organization of more IPC training for veterinary practitioners.

\section{Background}

SARS-Coronavirus-2 (SARS-CoV-2) is the agent that causes the disease COVID-19, first reported December 2019 in Wuhan China. (1)' (2) The virus, thought to have emerged from an animal source and spilled-over to human population. Although genetically closely related viruses were isolated from Rhinolophus bats (3), the source of SARS-CoV-2 and its route of introduction into human population has not been proven.

The first official case of COVID-19 in Nigeria was announced On Feb 27, 2020 (4) when a patient of Italian origin, arrived in Lagos from Europe. As at 9th May 2021 there were 165,382 confirmed cases with 2,065 deaths CFR 1.3\% across all the states in Nigeria,(5) with Lagos accounting for the highest $35 \%$ of the cases and $21 \%$ of deaths nationwide resulting into 58,743 cases and 439 deaths. This was followed closely by Abuja FCT with 19,842 cases and 166 deaths, Kaduna State with 9,068 cases and 65 deaths, Plateau State 9,060 cases and 57 deaths, Rivers State 7,174 cases and 33 deaths, (5) currently, all the 36 states have reported COVID-19 cases. Lower cases were reported in Kogi, Cross-Rivers and Taraba States. World Health Organization stated on 18 March 2020 that the number of cases in Africa was likely higher than reported, due to limited testing and deficiencies in emergency preparedness.

The Nigerian Centre for Disease Control is the government agency in charge of COVID-19 preparedness and response activities. A Coronavirus Preparedness Group was established at the end of January 2020 by the Nigerian government following the development of the epidemic in China. National NGOs, civil society organizations, international NGOs and UN agencies are also engaged in responding to the pandemic and the effects of COVID-19 containment measures.(6)

Health care workers had been in the fore front of the fight against the COVID-19 disease worldwide, from Doctors, nurses, epidemiologist, Pharmacist and other essential workers. During and after the lockdown, essential services such as hospitals, emergency services, security services, health workers, pharmacies, electricity and gas, food supply chains and veterinary establishments were in operation.(7) Veterinary practitioners as health care workers also play an important role in public health, animal health and food safety. When veterinary services received essential status at the onset of the pandemic, the industry 
pledged to limit non-essential procedures so that ventilators, surgical masks and other critical supplies could be conserved for use in human hospitals. But as essential workers themselves, faced with attending to animal patients and their owners, the risk of contracting the virus became higher.(8) In Lagos State, veterinary practitioners are found in both the public and private sectors delivering services such as animals disease and zoonosis diagnosis and treatment, vaccine administration, drug distribution, health education and providing direct patient care. This means that close contact with animal owners may be unavoidable and with limited PPE that was already diverted for use in human hospitals (8) this arm of health care workers became more vulnerable.

Although the current pandemic of COVID-19 is being sustained through human to human transmission, animal infections with SARS-CoV-2 have however been reported by several countries. Several animal species have proven to be susceptible to infection with SARS-CoV-2 either naturally or by experimental infection.(9) Important livestock species (pigs and poultry) have been demonstrated not to be susceptible to infection through experimental studies. (9) Further studies are however needed to understand if and how different animals could be affected by SARS-CoV-2. It is important to monitor infections in animals to better understand their epidemiological significance for animal health, biodiversity, and human health. Evidence from risk assessments, epidemiological investigations, and experimental studies do not suggest that live animals or animal products play a key role in SARS-CoV-2 infection of humans.(10) However Several animal species have tested positive for SARS-CoV-2, mostly as a result of close contact with humans infected with COVID-19 disease. (9) In animals, Knowledge about clinical disease manifestations is limited. Current evidence suggests clinical signs may include, but are not limited to, coughing, sneezing, respiratory distress, nasal discharge, ocular discharge, vomiting or diarrhea, fever, and lethargy. As in humans, asymptomatic infections also occur. (10)

With increase in cases of COVID-19 infection worldwide and the occurrence of community transmission of the disease in various community including Lagos Nigeria, it is important to be able to generate information on how the pandemic is affecting workers and patients in the animal health sector in Lagos, which is a major culprit in the origin and possible maintenance of the disease for future dissemination.

This study is meant to provide epidemiological information on the infection of covid-19 among veterinary practitioners that practiced during the Lagos lockdown, and to the best of our knowledge, it's the first to provide information on the COVID-19 status of canine in Lagos and by extension Nigeria. And also information on associated factors leading to a positive COVID-19 case between a veterinary practitioner and his canine contact. This will help policy makers to inform relevant training and policies during this or future zoonotic related outbreaks.

\section{Methods}

\section{Study design}

We used a retrospective cross-sectional study design for evaluations in our study. We received ethics approval from the Lagos State Veterinary Research Ethics Committee (LAGVREC) to obtain research data from veterinary practitioners and their canine contact for the duration of our study. (Reference number: LAGVREC/PRS/569T/159). The number of positive veterinary practitioners was obtained from questionnaires administered to respondents and response were cross checked with result presented on the Lagos State Surveillance Outbreak Response Management and Analysis System (SORMAS). An IgG/IgM COVID-19 test kit was used to determine number of COVID-19 cases among canine exposed to veterinary frontline health workers in Lagos.

Study setting

The study was carried out in Lagos State, Nigeria. Lagos State is a port city located in the southwestern geopolitical zone of Nigeria and has the smallest landmass of all 36 states in the country measuring 3,577 sq km.(11) Lagos State accounts for a large part of the economy of Nigeria and is the fifth largest economy in Africa. It is the most populated state in Nigeria with a population of 9,013,534 during the 2006 national census and a projected population of 14, 009,120 by 2020.(12)'(13) Lagos 
State is bounded in the North and east by Ogun State, in the west by Benin republic and in the south by the Atlantic Ocean.(11) Lagos is a cosmopolitan city and a home to different ethnic groups, however, the indigenous ethnic group is Yoruba. (11) It is the central hub of commerce in the country and a home to several industries such as construction, oil and gas, manufacturing, telecom and agriculture. (11) Lagos state is divided into five administrative regions and 20 local government areas (LGA).(14) The first COVID-19 case in Nigeria was an Italian, who came in through Lagos State's international airport on his way to Ogun State. Lagos was the epicenter of the outbreak of Covid-19 in Nigeria. There are currently 11 laboratories capable of testing for COVID-19 by RT-PCR in Lagos State; 4 public laboratories and 7 newly approved private laboratories.(15) There were 8 isolation centers located in Lagos State during the lockdown period for the isolation and treatment of COVID-19 positive patients with a 547 bed capacity.(15) In addition to 7 public run isolation centers, 1 private hospital later received approval to manage clients willing to pay for their services.(15)

Study population

\section{Human}

The study population include, all veterinary practitioners in Lagos State.

Inclusion criteria: All veterinary practitioners in the study population both in private and public service, working as frontline veterinary health workers in Lagos during the period of the COVID-19 pandemic lockdown from 1st June to 30th August 2020. Exclusion criteria: All persons in the inclusion criteria, whose clinic was not selected for sampling.

\section{Animal}

All canine, attended to or boarded by a veterinary hospital located within Lagos during the period of the COVID-19 pandemic from 1st June to 30th August 2020.

Inclusion Criteria: All canine in the study population that the owner gave permission to be sampled.

Exclusion Criteria: All canine in the inclusion criteria that cannot be restrained for sample collection.

Sample determination

Sample size of veterinary practitioners:

$\mathrm{N}=\mathrm{Z}{ }^{2} \mathrm{PQ} / \mathrm{d}^{2}$ - As described by (16)

Where: $\mathrm{N}$ = sample size

$Z$ = value for the corresponding confidence level (e.g., 1.96 for $95 \%$ confidence)

$\mathrm{P}=$ estimated value for the proportion of a sample/expected prevalence (6\%) (17)

$\mathrm{Q}=1-\mathrm{P}$,

$d=$ is the margin of error (e.g., $0.05= \pm 5 \%)$

$$
\mathrm{N}=\frac{1.96^{2} \times 0.06(1-0.06)}{0.05^{2}}=87
$$

A sample size of 87 respondents was estimated from the expected prevalence rate of $6 \%$ as described by (17). However, 112 veterinary practitioners were sampled as working during the COVID 19 lockdown period.

Sample size of canine tested:

All canine (complete sampling) exposed to the veterinary practitioners that served as frontline veterinary health workers during the period of the covid-19 pandemic lockdown from 1st June to 30th August, 2020 were sampled.

Sampling technique

A multistage sampling technique was adopted for the study. Lagos State is divided into five zones based on the geographical and socioeconomic distribution of the state (Fig. 1) which is also the distribution of the location of public veterinary health facilities in Lagos.

The five zones are, Ikeja, Badagry, Ikorodu, Lagos Island and Epe zones (IBILE). Four of these zones were then selected by simple random method. State public veterinary health facility within these zones, making up to five veterinary clinics were selected, in addition, four private veterinary clinic were randomly selected from the same zone as the public veterinary facility earlier selected this included Ikeja, Ikorodu, Lagos island and Badagry zones. A total of nine veterinary clinics were selected throughout Lagos State. Veterinary practitioners that worked in selected clinics during the period of the lock down, from $1 \mathrm{st}$ June to 30th August 2020, were all selected and a semi structured questionnaire administered to them either electronically or by an interviewer. Hospital case file register were then consulted to select the canine attended to by the selected clinics during the study period, all that fit the inclusion criteria were selected for sampling and their owners contacted by phone for approval. 
Case definition

Cases were defined using the case definition published by the Nigeria Center for Disease Control (NCDC).(18)

Confirmed case

Any person or canine with laboratory confirmation of SARS-CoV-2 infection either through PCR or IgG/IgM antibody RDT detection with or without signs and symptoms.

Study Instrument

The questionnaire was developed using Kobotool kit Platform to facilitate the completion and collection of data.

Questionnaires were administered to veterinary practitioner that meets the inclusion criteria by an interviewer or electronically through the department of veterinary services WhatsApp group, and a dog demographic questionnaire was administered to dog owners at both selected public and private veterinary clinics throughout Lagos.

IgG/IgM COVID-19 rapid test kit was used to test blood samples from canine that had contacts with the veterinary health workers in Lagos during the lockdown period.

Sample Collection Method

All canine attended to by veterinary practitioners from 1st June to 30th August, 2020 in the nine selected veterinary clinics in Lagos, with permission from their owners, were invited to the clinic and their blood sample were collected into plain blood sample bottles. Cephalic vein is the preferred route of collection, and blood was collected through a $5 \mathrm{ml} 18 \mathrm{~g}$ needle and syringe. The sample was stored in ice packs between $4^{0} \mathrm{c}$ to $8^{0} \mathrm{C}$ and transported to the laboratory for centrifugation. Serum was obtained from the clotted blood sample through $1500 \mathrm{rpm}$ for $10 \mathrm{~min}$ in the centrifuge machine. A drop of serum obtained is placed on the IgG/IgM COVID-19 rapid test kit's sample well for diagnosis. A total of 154 canines were sampled and all their result obtained and communicated to their individual clinic for proper handling of positive cases. A total of 112 questionnaires were administered to veterinary practitioners selected for the study to obtain their demographic information and their COVID-19 status was obtained by encouraging them to go for the voluntary PCR testing sponsored by the Lagos State government and NCDC, their sample collected and result confirmed through SORMASS.

Data questionnaire

The questionnaire was divided into two sections. The first section consisted of questions assessing socio-demographic, profession-related and COVID-19 profiles which were age, sex, COVID-19 status, name of clinic, type, LGA of clinic location, educational qualification, number of years post DVM, work cadre, marital status and number of persons in a household. The second section assessed exposures to canine patient and consist of 2 questions including, working within clinic area and close contact with patient at work.

Data analysis

We conducted descriptive statistics for all variables in the forms of frequencies proportions and percentages using Charts and tables on Microsoft Excel (2016). Maps of distributions of positive cases among veterinary practitioners and canine patients based on resident was also obtained and a bivariate analysis was carried out, all associations that are significant at this level was subjected to multivariate analysis using Epi-info 7.

\section{Results}

A total of 112 veterinary practitioners working in six LGA in Lagos State participated in the study. Of this, 76(68\%) are residing in urban areas of the state with the highest number 44(36\%) living in Ikeja LGA.

Table 1: Socio-demographic profile of veterinary practitioner respondents in the study from $1^{\text {st }}$ June $-30^{\text {th }}$ August, 2020 ( $n=$ 112). 


\begin{tabular}{|c|c|c|}
\hline $\mathrm{S} / \mathrm{N}$ & Variable & Proportion $(n=112)(\%)$ \\
\hline & Gender & \\
\hline \multirow[t]{5}{*}{1} & Male & $66(58.9 \%)$ \\
\hline & Female & $46(41.1 \%)$ \\
\hline & Age in years & \\
\hline & $20-29$ & $34(30.3 \%)$ \\
\hline & $30-39$ & $28(25.0 \%)$ \\
\hline \multirow[t]{7}{*}{2} & $40-49$ & $32(28.6 \%)$ \\
\hline & $50-59$ & $16(14.3 \%)$ \\
\hline & $60-69$ & $2(1.8 \%)$ \\
\hline & Clinic of practice & \\
\hline & Clinic 1 & $12(10.7 \%)$ \\
\hline & Clinic 2 & $8(7.1 \%)$ \\
\hline & Clinic 3 & $16(14.3 \%)$ \\
\hline \multirow[t]{7}{*}{3} & Clinic 4 & $22(19.6 \%)$ \\
\hline & Clinic 5 & $23(20.5 \%)$ \\
\hline & Clinic 6 & $4(3.6 \%)$ \\
\hline & Clinic 7 & $9(8.0 \%)$ \\
\hline & Clinic 8 & $4(3.6 \%)$ \\
\hline & Clinic 9 & $14(12.5 \%)$ \\
\hline & Type of clinic & \\
\hline \multirow[t]{4}{*}{4} & Private & $61(54.5 \%)$ \\
\hline & Government & $51(45.5 \%)$ \\
\hline & Type of resident & \\
\hline & Rural & $2(1.8 \%)$ \\
\hline \multirow[t]{2}{*}{5} & Semi-urban & $34(30.4 \%)$ \\
\hline & Urban & $76(67.8 \%)$ \\
\hline
\end{tabular}




\begin{tabular}{|c|c|c|}
\hline & \multicolumn{2}{|l|}{ LGA of resident } \\
\hline & Agege & $16(14.3 \%)$ \\
\hline & Alimosho & $6(5.4 \%)$ \\
\hline & Badagry & $4(3.6 \%)$ \\
\hline & Eti osa & $8(7.1 \%)$ \\
\hline & Ifako ijaye & $2(1.8 \%)$ \\
\hline \multirow[t]{8}{*}{6} & Ikeja & $44(39.3)$ \\
\hline & Ikorodu & $20(17.9 \%)$ \\
\hline & Kosofe & $4(3.6 \%)$ \\
\hline & Lagos mainland & $2(1.8 \%)$ \\
\hline & Ojo & $2(1.8 \%)$ \\
\hline & Surulere & $2(1.8 \%)$ \\
\hline & Non response & $2(1.8 \%)$ \\
\hline & Marital status & \\
\hline \multirow[t]{4}{*}{7} & Single & $36(32.1 \%)$ \\
\hline & Married & $76(67.9 \%)$ \\
\hline & Number of household & \\
\hline & Less than 5 & $66(58.9 \%)$ \\
\hline \multirow[t]{6}{*}{8} & $5-10$ & $32(28.6 \%)$ \\
\hline & $>10$ & $4(3.6 \%)$ \\
\hline & Non response & $10(8.9 \%)$ \\
\hline & Cadre of staff & \\
\hline & Veterinary doctor & $60(53.6 \%)$ \\
\hline & Veterinary nurse & $17(15.2 \%)$ \\
\hline \multirow[t]{7}{*}{9} & Veterinary technician & $8(7.1 \%)$ \\
\hline & Administrative staff & $8(7.1 \%)$ \\
\hline & Others & $18(16.1 \%)$ \\
\hline & Non response & $1(0.9 \%)$ \\
\hline & Highest education & \\
\hline & No formal education & $2(1.8 \%)$ \\
\hline & Primary education & $8(7.1 \%)$ \\
\hline \multirow[t]{4}{*}{10} & Secondary education & $18(16.1 \%)$ \\
\hline & Tertiary education & $62(55.4 \%)$ \\
\hline & Masters & $16(14.3 \%)$ \\
\hline & PHD & $6(5.3 \%)$ \\
\hline
\end{tabular}

Page 7/19 


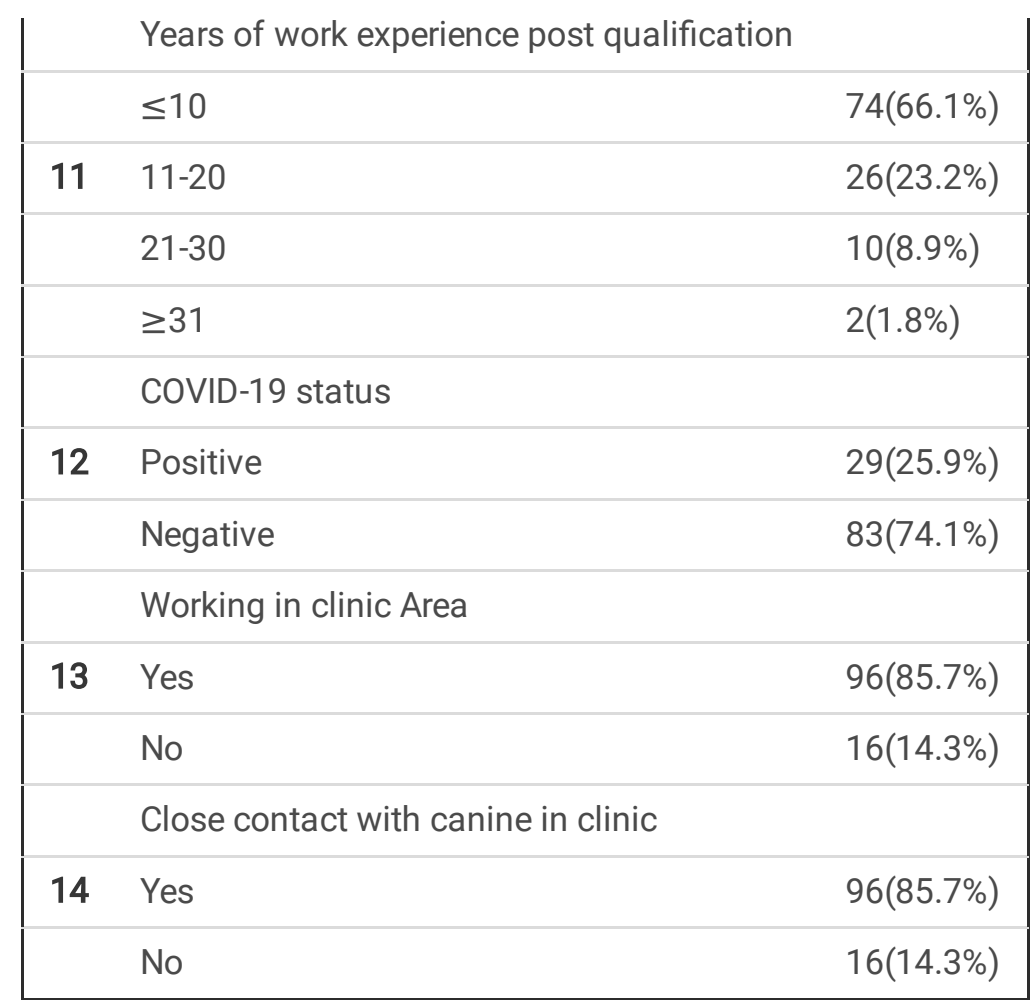

Table 2: Demographic profile of canine that participated in the study from $1^{\text {st }} \mathrm{June}-30^{\text {th }}$ August, $2020(n=154)$. 


\begin{tabular}{|c|c|c|}
\hline$S / N$ & Variable & Proportion $(n=154)(\%)$ \\
\hline & \multicolumn{2}{|l|}{ Clinic exposed to } \\
\hline & Clinic 1 & $18(11.7 \%)$ \\
\hline & Clinic 2 & $14(9.1 \%)$ \\
\hline & Clinic 3 & $40(26.0 \%)$ \\
\hline \multirow[t]{9}{*}{1} & Clinic 4 & $22(14.2 \%)$ \\
\hline & Clinic 5 & $8(5.2 \%)$ \\
\hline & Clinic 6 & $12(7.8 \%)$ \\
\hline & Clinic 7 & $10(6.5 \%)$ \\
\hline & Clinic 8 & $20(13.0 \%)$ \\
\hline & Clinic 9 & $10(6.5 \%)$ \\
\hline & LGA of resident & \\
\hline & Agege & $23(14.9 \%)$ \\
\hline & Bagagry & $12(7.8 \%)$ \\
\hline \multirow[t]{6}{*}{2} & Eti-osa & $10(6.5 \%)$ \\
\hline & Ibeju lekki & $10(6.5 \%)$ \\
\hline & Ikeja & $48(31.2 \%)$ \\
\hline & Ikorodu & $31(20.1 \%)$ \\
\hline & Surulere & $20(13.0 \%)$ \\
\hline & Type of clinic Attended & \\
\hline \multirow[t]{3}{*}{3} & Private & $74(48.1 \%)$ \\
\hline & Government & $80(51.9 \%)$ \\
\hline & COVID-19 serological result & \\
\hline \multirow[t]{2}{*}{4} & Positive & $3(2.0 \%)$ \\
\hline & Negative & $151(98.0 \%)$ \\
\hline
\end{tabular}

Table 3: Bivariate analysis of exposures in relations to COVID-19 among veterinary practitioner's front line workers in Lagos $1^{\text {st }}$ June $-30^{\text {th }}$ August, $2020(n=112)$. 


\begin{tabular}{|c|c|c|c|c|c|}
\hline \multirow[t]{2}{*}{ Variable } & \multirow[t]{2}{*}{ Exposure } & \multirow{2}{*}{$\begin{array}{l}\text { Positive (\% of } \\
\text { positive) } \\
\mathrm{N}=29\end{array}$} & \multirow{2}{*}{$\begin{array}{l}\text { Negative (\% of } \\
\text { negative) } \\
\mathrm{N}=83\end{array}$} & \multirow[t]{2}{*}{$\begin{array}{l}\text { OR( } 95 \% \mathrm{Cl} \text { lower- } \\
\text { upper) }\end{array}$} & \multirow[t]{2}{*}{ P-value } \\
\hline & & & & & \\
\hline \multirow[t]{2}{*}{ Gender } & Male & 21(31.8) & $45(68.2)$ & $2.22(0.88-5.57)$ & 0.12 \\
\hline & Female & $8(17.4)$ & $38(82.6)$ & & \\
\hline \multirow[t]{2}{*}{ Age(years) } & $<40$ & 18(29) & $44(71)$ & $1.45(0.61-3.45)$ & 0.52 \\
\hline & $\geq 40$ & 11(22) & $39(78)$ & & \\
\hline \multirow[t]{2}{*}{ Type of clinic } & Private & $16(26.2)$ & $45(73.8)$ & $1.04(0.44-2.43)$ & 1.00 \\
\hline & Government & $13(25.5)$ & $38(74.5)$ & & \\
\hline \multirow{2}{*}{$\begin{array}{l}\text { Exposed to clinic } \\
1\end{array}$} & Yes & $2(16.7)$ & 10(83.3) & $0.54(0.11-2.63)$ & 0.73 \\
\hline & No & $27(27)$ & 73(73) & & \\
\hline \multirow[t]{2}{*}{ Clinic 2} & Yes & $0(0)$ & $8(100)$ & 0.00 & 0.11 \\
\hline & No & $29(27.9)$ & $75(72.1)$ & & \\
\hline \multirow[t]{2}{*}{ Clinic 3} & Yes & 16(100) & $0(0)$ & & \\
\hline & No & 13(13.5) & $83(86.5)$ & & \\
\hline \multirow[t]{2}{*}{ Clinic 4} & Yes & $9(40.9)$ & $13(59.1)$ & $2.42(0.91-6.47)$ & 0.10 \\
\hline & No & $20(22.2)$ & 70(77.8) & & \\
\hline \multirow[t]{2}{*}{ Clinic 5} & Yes & $0(0)$ & $23(100)$ & 0.00 & $0.0008 *$ \\
\hline & No & $29((32.6)$ & $60(67.4)$ & & \\
\hline \multirow[t]{2}{*}{ Clinic 6} & Yes & $0(0)$ & $4(100)$ & 0.00 & 0.57 \\
\hline & No & $29(26.9)$ & 79(73.1) & & \\
\hline \multirow[t]{2}{*}{ Clinic 7} & Yes & $2(22.2)$ & $7(77.8)$ & $0.80(0.16-4.11)$ & 1.00 \\
\hline & No & $27(26.2)$ & 76(73.8) & & \\
\hline \multirow[t]{2}{*}{ Clinic 8} & Yes & $0(0)$ & $49(100)$ & 0.00 & $0.02^{*}$ \\
\hline & No & $29(26.9)$ & 79(73.1) & & \\
\hline \multirow[t]{2}{*}{ Clinic 9} & Yes & $0(0)$ & $14(100)$ & 0.00 & $0.02^{*}$ \\
\hline & No & $29(29.6)$ & $69(70.4)$ & & \\
\hline \multirow[t]{7}{*}{ Zone of resident } & $\begin{array}{l}\text { Badagry } \\
\text { (Yes) }\end{array}$ & $2(16.7)$ & 10(83.3) & 0.53 & 0.51 \\
\hline & (No) & $27(27.6)$ & 71(72.4) & & \\
\hline & Ikeja (Yes) & 23(37.1) & $39(62.9)$ & $4.12(1.52-11.2)$ & $0.004^{*}$ \\
\hline & (No) & $6(12.5)$ & $42(87.5)$ & & \\
\hline & $\begin{array}{l}\text { Ikorodu } \\
\text { (Yes) }\end{array}$ & $0(0)$ & $24(100)$ & 0.00 & $0.0004^{*}$ \\
\hline & (No) & 29(33.7) & $57(66.3)$ & & \\
\hline & $\begin{array}{l}\text { Lagos } \\
\text { Island(Yes) }\end{array}$ & $4(33.3)$ & $8(66.7)$ & $1.46(0.41-5.27)$ & 0.73 \\
\hline
\end{tabular}




\begin{tabular}{|c|c|c|c|c|c|}
\hline & (No) & $25(25.5)$ & $73(74.5)$ & & \\
\hline \multirow{2}{*}{$\begin{array}{l}\text { Residential } \\
\text { location }\end{array}$} & Urban & $26(34.2)$ & $50(65.8)$ & $5.72(1.60-20.44)$ & $0.003^{\star}$ \\
\hline & Semi Urban & $3(8.3)$ & $33(91.7)$ & & \\
\hline \multirow[t]{2}{*}{ Marital status } & Married & 15(19.7) & $61(80.3)$ & $0.38(0.16-0.93)$ & $0.04 *$ \\
\hline & Single & 14(38.9) & $22(61.1)$ & & \\
\hline \multirow[t]{2}{*}{$\mathrm{H} / \mathrm{H}$ members } & $<5$ & 21(31.8) & $45(68.2)$ & $1.63(0.64-4.19)$ & 0.36 \\
\hline & $\geq 5$ & $8(22.2)$ & $28(77.8)$ & & \\
\hline \multirow[t]{2}{*}{ Cadre of staff } & Vet. doctor & $22(36.7)$ & $38(63.3)$ & $3.64(1.40-9.46)$ & $0.009 *$ \\
\hline & Others & 7(13.7) & $44(86.3)$ & & \\
\hline \multirow[t]{2}{*}{ Education level } & Tertiary & $26(40)$ & $58(60)$ & $3.74(1.04-13.49)$ & $0.05^{*}$ \\
\hline & Bellow tertiary & $3(10.7)$ & 25(89.3) & & \\
\hline \multirow{2}{*}{$\begin{array}{l}\text { Years of } \\
\text { experience }\end{array}$} & $\leq 10$ years & $22(29.7)$ & $52(70.3)$ & $1.87(0.72-4.89)$ & 0.26 \\
\hline & $>10$ years & $7(18.4)$ & $31(81.6)$ & & \\
\hline \multirow{2}{*}{$\begin{array}{l}\text { Working within } \\
\text { clinic }\end{array}$} & Yes & $24(25)$ & $72(75)$ & $0.73(0.23-2.32)$ & 0.55 \\
\hline & No & $5(31.3)$ & $11(68.7)$ & & \\
\hline \multirow{2}{*}{$\begin{array}{l}\text { Close contact with } \\
\text { canine in clinic }\end{array}$} & Yes & $25(26.3)$ & $70(73.7)$ & $1.55(0.41-5.89)$ & 0.76 \\
\hline & No & $3(18.8)$ & $13(81.2)$ & & \\
\hline
\end{tabular}

Table 4: Bivariate analysis of associations in relations to COVID-19 among Canine exposed to veterinary practitioner's front line workers in Lagos $1^{\text {st }}$ June $-30^{\text {th }}$ August, $2020(n=154)$. 


\begin{tabular}{|c|c|c|c|c|c|}
\hline \multirow[t]{2}{*}{ Variable } & \multirow[t]{2}{*}{ Exposure } & \multirow{2}{*}{$\begin{array}{l}\text { Positive (\% of } \\
\text { positive) } \\
\mathrm{N}=3\end{array}$} & \multirow{2}{*}{$\begin{array}{l}\text { Negative (\% of } \\
\text { negative) } \\
\mathrm{N}=151\end{array}$} & \multirow[t]{2}{*}{$\begin{array}{l}\text { OR(95\% Cl lower- } \\
\text { upper) }\end{array}$} & \multirow[t]{2}{*}{$\begin{array}{l}\mathrm{P} \text { - } \\
\text { value }\end{array}$} \\
\hline & & & & & \\
\hline \multirow{6}{*}{$\begin{array}{l}\text { Canine exposure to } \\
\text { clinic }\end{array}$} & Clinic 2 & $1(7.7)$ & $12(92.3)$ & $5.79(0.49-68.60)$ & 0.23 \\
\hline & Exposed & & & & \\
\hline & $\begin{array}{l}\text { Not } \\
\text { exposed }\end{array}$ & $2(1.4)$ & 139(98.6) & & \\
\hline & Clinic 3 & $2(5)$ & $38(95)$ & $6.94(0.52-67.45)$ & 0.16 \\
\hline & Exposed & & & & \\
\hline & $\begin{array}{l}\text { Not } \\
\text { exposed }\end{array}$ & $1(0.9)$ & 113(99.1) & & \\
\hline \multirow{6}{*}{$\begin{array}{l}\text { Canine Resident by } \\
\text { zone }\end{array}$} & Ikeja & $2(2.8)$ & $69(97.2)$ & $2.37(0.21-26.78)$ & 0.44 \\
\hline & Yes & & & & \\
\hline & No & $1(1.2)$ & 82(98.8) & & \\
\hline & Ikorodu & $1(3.2)$ & $30(96.8)$ & $2.02(0.18-22.99)$ & 0.49 \\
\hline & Yes & & & & \\
\hline & No & $2(1.6)$ & $121(98.4)$ & & \\
\hline
\end{tabular}

Table 5: Multivariate analysis of associated factors, Covid-19 veterinary practitioner front line workers in Lagos $1^{\text {st }} \mathrm{June}-30^{\text {th }}$ August, $2020(n=112)$.

\begin{tabular}{|llll|}
\hline Variables & Adjusted Odds Ratio & 95\% Confidence Interval & P-value \\
\hline Was staff a doctor (Cadre of staff) & 2.71 & $(0.84,8.69)$ & 0.09 \\
\hline Educational qualification (tertiary or bellow) & 2.27 & $(0.47,10.91)$ & 0.31 \\
\hline Marital status (single/married) & 2.07 & $(0.74,5.79)$ & 0.17 \\
\hline Staying in places different from ikeja. & 0.26 & $(0.08,0.8)$ & $0.019^{*}$ \\
\hline Type of residential location (Urban/) & 3.44 & $(0.81,14.72)$ & 0.096 \\
\hline
\end{tabular}

\section{Discussion}

With this study, we now have an understanding on the presence of Covid-19 infection among domestic animals, specifically canine resident in Lagos during the lockdown period and the status of their veterinary handlers in relation to the factors associated with the infection, which is essential for the profession to thrive during the post lock down era. Such knowledge can help to contain the pandemic among this group of essential service providers post lock down through adopting the right approach and precautionary measures, which will invariably boost both the physical and mental health of veterinarians and the society at large.(8)

According to this study the male gender was more (59\%) than the female, this is attributable to the fact that the veterinary profession is considered as a masculine career with many of the female graduates restricting themselves to academia or the 
small animal medicine which is less physically tasking. Although recent trends in advance countries are showing the involvement of more women in the profession (19), Nigeria is however backwards in this regards (8)

The major age range of our respondents was 20-29 years (30.3\%) and 40-49 years (28.6\%) which were majorly from the private sector $(54.5 \%)$ and resident majorly in the urban (67.8\%) settlement of Lagos state, this could be because the private veterinary establishments located in the urban areas are the larger employer of veterinary practitioners in Lagos than the public sector, this is however in contrast to the national study (8) carried out on similar population using strictly online survey as against our study that used majorly interviewer administered method. Veterinary doctors (53.6\%) were the major respondents with those having less than 10 years of experience (66.1\%) predominating.

A total of 29 respondents ranging from veterinary doctors, nurses, technician, attendants and security personnel, returned a positive COVID-19 result, accounting for $25.9 \%$ among this front line responders. This is however quite high when compared to the proportion of COVID-19 cases of health care workers in the general population 3.8\%.(20) and the prevalence of COVID-19 in the general population of $2.7 \%$.(12)'(21)

For the canine sampled, the highest proportion came from Ikeja LGA (31.2\%) which belong to the ikeja zone of Lagos (11) that houses the headquarters of the state veterinary hospital, which was opened during the entire lockdown period in Lagos. A total of $51.9 \%$ of the canine sampled came from the public veterinary clinics although the private veterinary establishment accounted for all the 2\% COVID-19 positive canine cases that were detected during our study. This is however smaller than the $21-53 \%$ sero-prevalence gotten from a study of 41 pets (canine and feline) belonging to COVID-19 positive patients in France, (21) reasons could be because pets in this study were specifically from positive patients while my study was from contacts of veterinary practitioners. Secondly my study has about three times the sample size of the published study hence making it more representative.

With $25.9 \%$ of the respondent returning a COVID-19 positive result, we further investigated the associated factors of COVID-19 infection among them and found out that veterinary practitioners residing in Ikeja were 4.12 times more likely to return a COVID-19 positive result than those residing in other LGA in Lagos. This could be because lkeja was one of the LGA in Lagos with the highest COVID-19 positive cases and community transmission of the infection was already identified during the period of this study.(22) Respondents living in an urban settlement were also 5.7 times more likely to be positive than those living in rural areas, this is because the initial cases of the disease were those with history of travelling outside the country usually to Europe or Asian and American countries and their contacts, and because they are mostly rich to average Nigerian, they are more likely to reside in urban settlement as against rural settlements.

Being married was protective of COVID-19 among our respondents, this is because married couple will tend to adhere more to the stay at home measures instituted by the Lagos state government during the lockdown period than single individuals who are more likely to go for parties and events that may attract other singles.

In our study, veterinary doctors where 3.6 times more likely to return a COVID-19 positive result than other veterinary practitioners, this could be related to their interaction with clients and the patient. Veterinary doctors are responsible for interviewing the clients to obtain history and other signalment of their pet and in doing this they usually have close contacts with both patient and clients, making the risk of infection highest for veterinary doctors than other veterinary practitioners.

Having tertiary education was also associated with COVID-19 infection. This could be related to the massive misinformation that were trending on social-media, news media and the internet as a whole, and since majority of internet and news media users are people with tertiary education and above,(23) they may tend to be believers of controversies against social distancing and other non-pharmacological COVID-19 preventive measures, hence exposing this group of individuals to a higher risk of getting infected.

The bivariate analysis of possible relationship of COVID-19 positive canine sampled in our study with clinics and residential location of COVID-19 positive veterinary practitioners showed that the odd of getting the infection among canine in relation to their visit or being resident in clinic (clinic 2 and 3) and the residential location of the animal (Ikeja and Ikorodu), were 5.79, 
6.94, 2.37 and 2.02 respectively, even though all were not statistically significant. This may be because only 3 out of the 154 canine sampled returned a positive result.

At the multivariate analysis level, staying in Ikeja LGA was a risk of having COVID-19 infection among the veterinary practitioners sampled. All other associations at bivariate level were not statistically significant at this level.

It is however pertinent to say that there were some limitations to our study, being the foremost survey on COVID-19 among canine in Lagos and most likely Nigeria, we had the challenge of the right test kits to use for diagnosis, wining the trust of the Lagos State ministry of Agriculture and convincing veterinary practitioner respondents of the importance of the study. More study is however needed in future when COVID-19 diagnostic test kits for animals especially canine are readily available for a better sensitivity and specificity.

\section{Conclusion}

In conclusion COVID-19 infection do occur in canine based in Lagos as 3 positive cases where recorded in Ikeja and Ikorodu LGA among those in contact with veterinary practitioners during the lockdown. Veterinary practitioners that were on duty during the lockdown had a COVID-19 prevalence of $25.9 \%$, which was associated with residing in Ikeja, staying in an urban settlement, being single, being a veterinary doctor working during lockdown, and having tertiary education. There was no significant relationship between a covid-19 positive veterinary practitioner and their canine contact in Lagos during the lockdown period. Training and workshops on COVID-19 IPC should be organized for all veterinary practitioners in Lagos both public and private sector and adequate attention should be placed on this arm of first responders in future, by the Lagos State government in terms of provision of PPE and other IPC related consumables.

\section{Abbreviations}

LGA

Local government area.

CFR

Case fatality rate

WHO

World health organization

OR

Odd ratio

IPC

Infection prevention and control

FCT

Federal capital territory

NGO

Non-governmental organization

UN

United nations

DVM

Doctor of veterinary medicine

NCDC

Nigerian center for disease control

PCR

Polymerase chain reaction

IgG/lgM

Immunoglobulin G/ Immunoglobulin M 


\section{Declarations}

\section{Ethics approval and consent to participate}

We received ethics approval from the Lagos State Veterinary Research Ethics Committee (LAGVREC) to obtain research data from veterinary practitioners and their canine contact for the duration of our study.

\section{Consent to publish}

Not applicable.

\section{Availability of Data and Materials}

All data generated or analyzed during this study are included in this published article [and its supplementary information files].

\section{Competing interests}

The authors declare that they have no competing interests.

\section{Funding}

This research was self-funded by the author.

\section{Author's contributions}

FOS drafted the manuscript, designed the questionnaire and collected the data. FOS also performed the statistical analysis. E.O.O, S.N.G, AU AND O.A revised the manuscript critically for important intellectual content. All the authors listed read and approved the final manuscript.

\section{Acknowledgement}

I wish to acknowledge the effort and co-operation of staffs and principal officers of the department of veterinary services, Lagos state ministry of agriculture Nigeria. Their effort in ensuring the success of this study in Lagos is indeed very commendable.

\section{References}

1. Reuben RC, Danladi MMA, Saleh DA, Ejembi PE. Knowledge, Attitudes and Practices Towards COVID-19: An Epidemiological Survey in North-Central Nigeria. J Community Health [Internet]. 2020 Jul 7 [cited 2020 Aug 25];1-14. Available from: https://doi.org/10.1007/s10900-020-00881-1

2. How Coronavirus Spreads | CDC [Internet]. [cited 2020 Oct 11]. Available from: https://www.cdc.gov/coronavirus/2019ncov/prevent-getting-sick/how-covid-spreads.html?

CDC_AA_refVal=https\%3A\%2F\%2Fwww.cdc.gov\%2Fcoronavirus\%2F2019-ncov\%2Fabout\%2Findex.html

3. Bats Might Be Origin of SARS I The Scientist Magazine ${ }^{\circledR}$ [Internet]. [cited 2020 Oct 8]. Available from: https://www.thescientist.com/news-opinion/bats-might-be-origin-of-sars-48326

4. Kalu B. COVID-19 in Nigeria: a disease of hunger. Lancet Respir Med [Internet]. 2020 Jun 1 [cited 2020 Oct 1];8(6):556-7. Available from: https://www.ncbi.nlm.nih.gov/pmc/articles/PMC7190300/

5. NCDC Coronavirus COVID-19 Microsite [Internet]. [cited 2021 May 19]. Available from: https://covid19.ncdc.gov.ng/report/\#!

6. Coronavirus disease (COVID-19) [Internet]. [cited 2020 Oct 18]. Available from: https://www.who.int/emergencies/diseases/novel-coronavirus-2019? gclid=CjwKCAjwrKr8BRB_EiwA7eFapjmGLKmku6no_Or9SsnxYSzqColxlfaNqZGPd3sT8gcPWgw9IG0hTxoCaFYQAvD_BwE 
7. Nigeria Centre for Disease Control [Internet]. [cited 2020 Feb 19]. Available from: https://ncdc.gov.ng/reports/weekly

8. Tolulope Adenubi O, Oluseun Adebowale O, Adetokunbo Oloye A, Olumide Bankole N, Kehinde Adesokan H, Ebenezer Fadipe O, et al. Level of Knowledge, Attitude and Perception About COVID-19 Pandemic and Infection Control: A CrossSectional Study Among Veterinarians in Nigeria. 2020;(July):1-27. Available from: www.preprints.org

9. Pets and Other Animals | CDC [Internet]. [cited 2020 Oct 25]. Available from: https://www.cdc.gov/coronavirus/2019ncov/animals/pets-other-animals.html

10. INFECTION WITH SARS-COV-2 IN ANIMALS. 2020.

11. Population-Lagos State [Internet]. Lagos State Government; [cited 2020 Oct 29]. Available from: http://www.lagosstate.gov.ng/pagelinks.php?p=6

12. Biggs HM, Harris JB, Breakwell L, Dahlgren FS, Abedi GR, Szablewski CM, et al. Estimated Community Seroprevalence of SARS-CoV-2 Antibodies - Two Georgia Counties, April 28-May 3, 2020. MMWR Morb Mortal Wkly Rep [Internet]. 2020 Jul 24 [cited 2020 Oct 29];69(29):965-70. Available from: http://www.cdc.gov/mmwr/volumes/69/wr/mm6929e2.htm? s_cid=mm6929e2_w

13. Wolfson LJ, Strebel PM, Grais RF, Luquero FJ, Birmingham ME. Estimates of measles case fatality ratios: a comprehensive review of community-based studiest. Int J Epidemiol [Internet]. 2009 Jan 30;38(1):192-205. Available from:

https://doi.org/10.1093/ije/dyn224

14. Lagos State Government - Centre of Excellence [Internet]. [cited 2020 Oct 29]. Available from: https://lagosstate.gov.ng/

15. Lagos approves seven private laboratories for COVID-19 testing - Healthwise [Internet]. [cited 2020 Oct 29]. Available from: https://healthwise.punchng.com/lagos-approves-seven-private-laboratories-for-covid-19-testing/

16. Omair A. Sample size estimation and sampling techniques for selecting a representative sample. J Heal Spec [Internet]. 2014 [cited 2020 Nov 9];2(4):142. Available from: https://www.thejhs.org/article.asp?issn=24686360;year=2014; volume=2;issue $=4$; spage=142; epage=147; aulast $=$ Omair

17. Self WH, Tenforde MW, Stubblefield WB, Feldstein LR, Steingrub JS, Shapiro NI, et al. Seroprevalence of SARS-CoV-2 Among Frontline Health Care Personnel in a Multistate Hospital Network - 13 Academic Medical Centers, April-June 2020. MMWR Morb Mortal Wkly Rep [Internet]. 2020 Sep 4 [cited 2020 Oct 18];69(35):1221-6. Available from: http://www.cdc.gov/mmwr/volumes/69/wr/mm6935e2.htm?s_cid=mm6935e2_w

18. Nigeria Centre for Disease Control [Internet]. [cited 2020 Nov 1]. Available from: https://ncdc.gov.ng/diseases/guidelines

19. Gender and veterinary medicine [Internet]. [cited 2021 May 1]. Available from:

https://www.ncbi.nlm.nih.gov/pmc/articles/PMC340187/

20. Epidemiology of COVID-19 [Internet]. [cited 2020 Oct 14]. Available from: https://www.ecdc.europa.eu/en/covid-19/latestevidence/epidemiology

21. Fritz M, Rosolen B, Krafft E, Becquart P, Elguero E, Vratskikh O, et al. High prevalence of SARS-CoV-2 antibodies in pets from COVID-19 + households. One Heal. 2021 Jun 1;11:100192.

22. Onasanya O, Adebayo B, Okunromade L, Abayomi A, Idris J, Adesina A, et al. Predictive ability of symptomatology in COVID-19 during Active case search in Lagos State, Nigeria. Niger Postgrad Med J [Internet]. 2020 Oct 1 [cited 2021 May 7];27(4):280-4. Available from:https://www.npmj.org/article.asp? issn=11171936; year=2020; volume=27;issue=4; ;page=280; epage=284; aulast=Onasanya

23. Hussain ZA, Hussain SA, Hussain FA. Medical students' knowledge, perceptions, and behavioral intentions towards the H1N1 influenza, swine flu, in Pakistan: A brief report. Am J Infect Control [Internet]. 2012 Apr [cited 2021 May 2];40(3). Available from: https://pubmed.ncbi.nlm.nih.gov/22361359/

\section{Additional File}

Additional File 1 is not available in this version

\section{Figures}

Page 16/19 


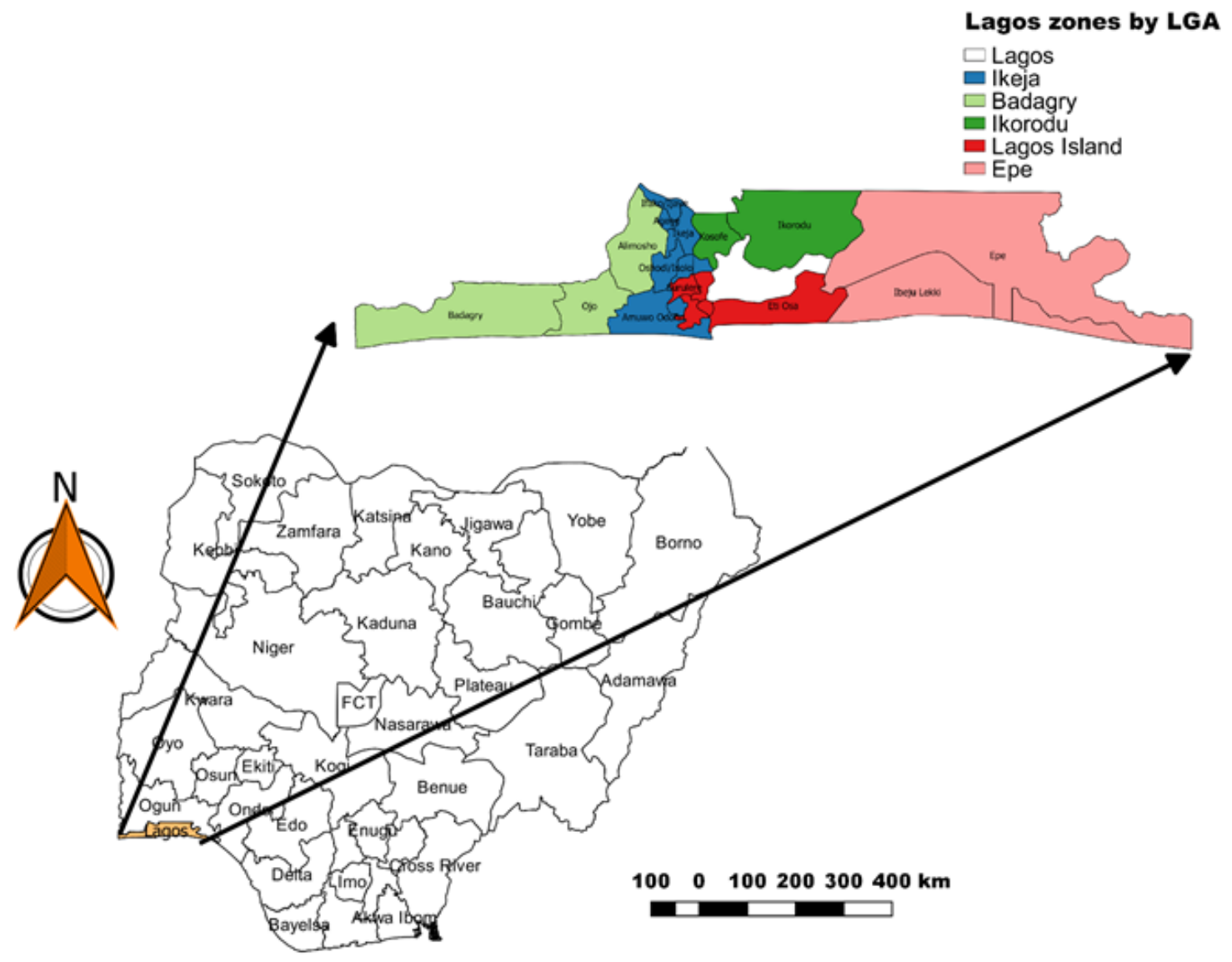

\section{Figure 1}

Map of Nigeria, with the zonal division of Lagos (IBILE). This shows the map of Nigeria, highlighting the zonal division of Lagos State into five (IBILE) with each zones representing a different color. The zonal division was used during sampling, to choose the appropriate veterinary clinic to be selected for sample collection for representativeness. 

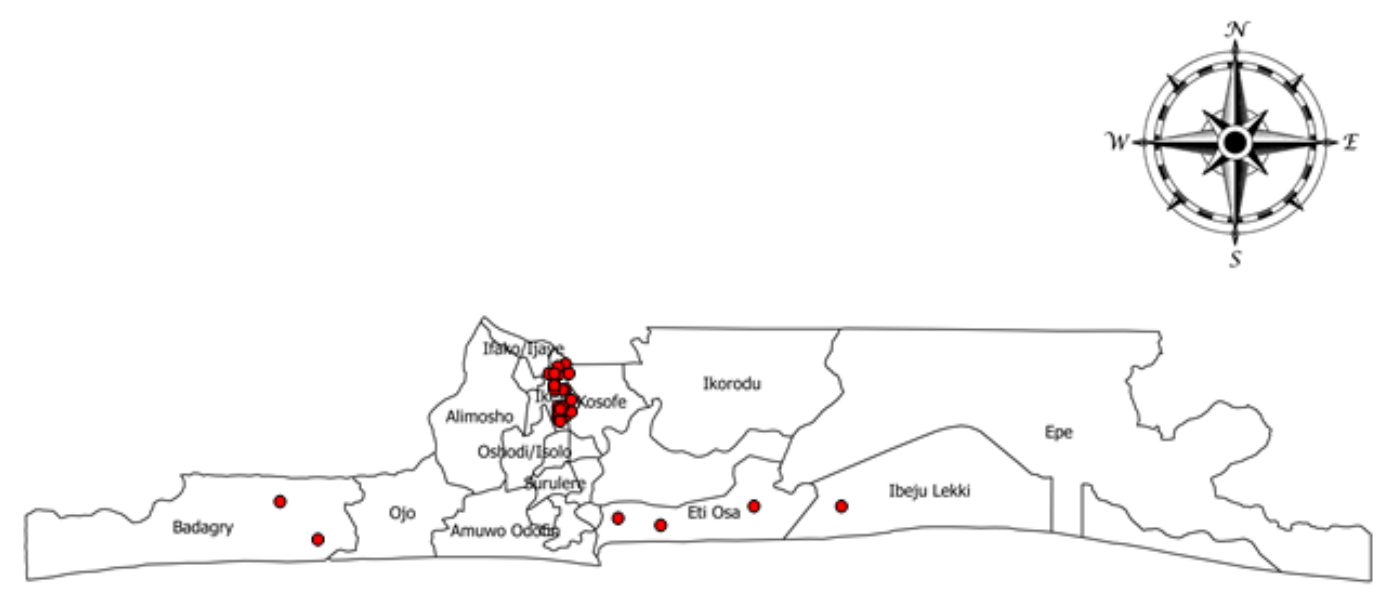

- Veterin ARY PRACTITIONERS COVID-19 CASE

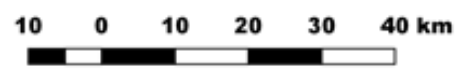

LAGOS LGA

\section{Figure 2}

COVID-19 cases among veterinary practitioners in Lagos by LGA of residency, 1 st June - 30th August 2020. This showed the number and distribution of positive COVID-19 cases among veterinary practitioners in Lagos State, within the period of the study. A total of $25.9 \%$ of veterinary practitioners sampled returned a positive result.
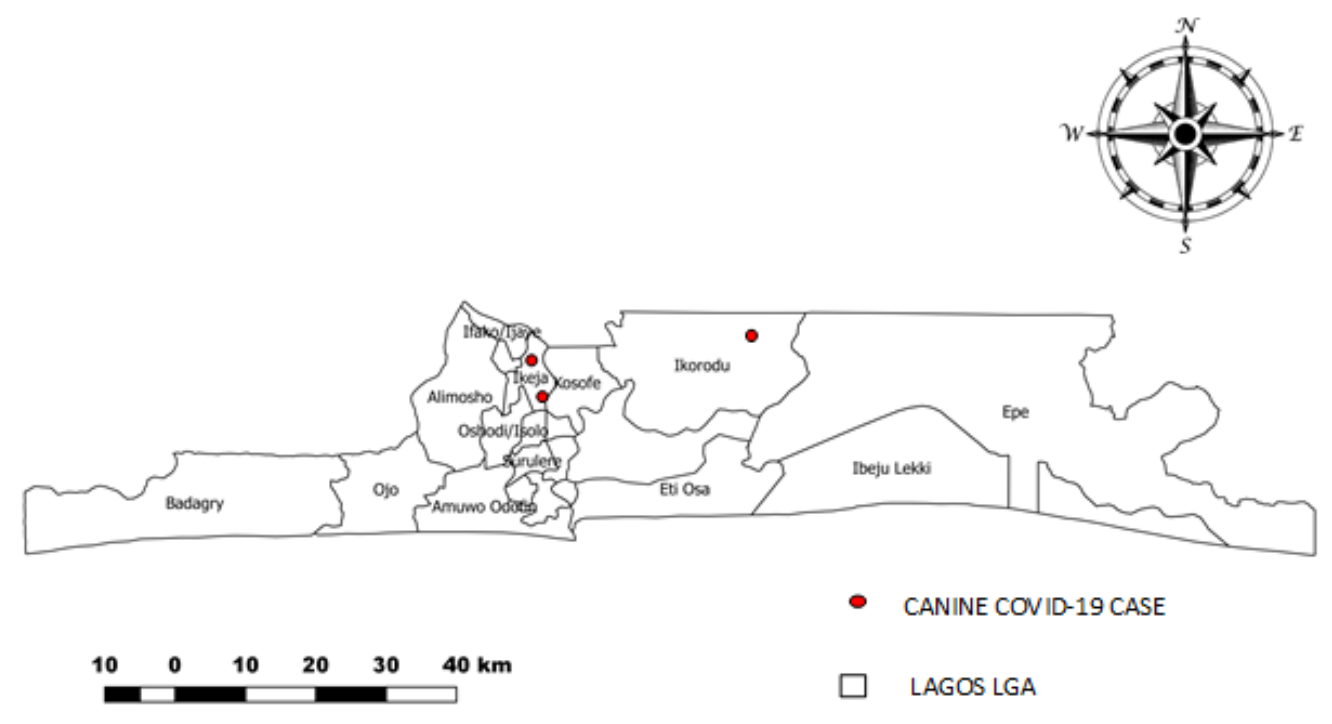


\section{Figure 3}

Canine COVID-19 cases in Lagos by LGA of residency, 1 st June to 30th August 2020. This showed the number and distribution of positive COVID-19 cases among Canine in Lagos State, within the period of the study. A total of $2.0 \%$ of canine sampled returned a positive result.

\section{Supplementary Files}

This is a list of supplementary files associated with this preprint. Click to download.

- Additionalfile2.xlsx 